\title{
High mortality of loggerhead turtles due to bycatch, human consumption and strandings at Baja California Sur, Mexico, 2003 to 2007
}

\author{
S. Hoyt Peckham ${ }^{1,2, *}$, David Maldonado-Diaz ${ }^{2}$, Volker Koch ${ }^{3}$, Agnese Mancini ${ }^{3}$, \\ Alexander Gaos ${ }^{2}$, M. Tim Tinker ${ }^{1}$, Wallace J. Nichols ${ }^{4,5}$ \\ ${ }^{1}$ Dept of Ecology and Evolutionary Biology, University of California at Santa Cruz, Santa Cruz, California 95060, USA \\ ${ }^{2}$ Grupo Tortuguero A.C./ProPeninsula, La Paz, Baja California Sur 23060, Mexico \\ ${ }^{3}$ Universidad Autónoma de Baja California Sur, La Paz, Baja California Sur 23080, Mexico \\ ${ }^{4}$ California Academy of Sciences, San Francisco, California 94118, USA \\ ${ }^{5}$ Ocean Revolution, Davenport, California 95017, USA
}

\begin{abstract}
Assessing mortality of long-lived organisms is fundamental for understanding population trends and for implementing conservation strategies, but doing so for marine megafauna is challenging. Here we assessed anthropogenic mortality of endangered North Pacific loggerhead turtles in the coastal waters of Baja California Sur, Mexico (BCS), through the synthesis of 3 sources: (1) intensive surveys of an index shoreline from 2003 to 2007; (2) bimonthly surveys of additional shorelines and towns for stranded and consumed carcasses from 2006 to 2007; and (3) observations of bycatch by 2 small-scale fishing fleets. Using Monte Carlo simulations we estimate that 1500 to 2950 loggerhead turtles died per year at BCS from 2005 to 2006 due to bycatch in the 2 observed fleets. Actual mortality may be considerably higher due to bycatch in other fisheries, directed hunting for black market trade, and natural factors including predation and disease. From 2003 to 2007 we encountered 2719 loggerhead carcasses on shorelines and in and around towns of BCS. Along the $43 \mathrm{~km}$ Playa San Lázaro, 0.25 loggerheads $\mathrm{km}^{-1} \mathrm{~d}^{-1}$ were stranded during summer fishing months over $5 \mathrm{yr}$, which is among the highest reported stranding rates worldwide. This stranding rate corroborates similarly high observed bycatch rates for local small-scale longline (29 loggerheads 1000 hooks ${ }^{-1}$ ) and gillnet (1.0 loggerhead $\mathrm{km}^{-1}$ of net) fisheries. A significant increase in mean length of 2636 carcasses measured at BCS occurred from 1995 to 2007. Given the endangered status of the North Pacific loggerhead population, conservation action to reduce bycatch and poaching at BCS is urgently needed.
\end{abstract}

KEY WORDS: Loggerhead sea turtle $\cdot$ Bycatch $\cdot$ Small-scale fisheries $\cdot$ Wildmeat $\cdot$ Poaching Strandings $\cdot$ Mass mortality $\cdot$ Length frequency $\cdot$ Marine conservation

\section{INTRODUCTION}

Marine megafauna, including predatory fish, seabirds, marine mammals, and sea turtles, have declined worldwide due to anthropogenic threats such as overfishing, bycatch, infectious disease, and habitat loss (Jackson et al. 2001, Myers \& Worm 2003, Aguirre \& Tabor 2004, Lewison et al. 2004a). Many of these declines result from reduced survival rates, and deter- mining these rates is important for understanding population trends and for developing and implementing conservation strategies (NRC 1995, Morris \& Doak 2002). However, assessing survivorship during the oceanic life stages of marine megafauna populations is notoriously difficult due to their oceanwide distributions, generally low densities, and the resulting challenges of direct observation. The demography of seabirds and sea turtles, for instance, is fairly well 
understood during nesting, but relatively little is known about their oceanic life stages and developmental migrations. Elucidating these life stages is a conservation priority (NRC 1990, NMFS 2007).

Developmental migrations that last decades and take juvenile North Pacific loggerhead turtles from their Japanese rookeries as far as Mexico (Bowen et al. 1995, Nichols 2003) have precluded understanding the dynamics of the population. Censuses of Japanese rookeries showed declines in nesting females as high as $90 \%$ within the past 3 generations to fewer than $1000 \mathrm{yr}^{-1}$, qualifying the population for critically endangered status (Kamezaki et al. 2003). Nesting abundance throughout the Japanese archipelago has fluctuated at historically low levels over the past 2 decades, exhibiting a quasi-cyclic trend that may be environmentally induced (Chaloupka et al. 2008, N. Kamezaki et al. unpubl. data).

Where they aggregate at foraging grounds in the central North Pacific, juvenile loggerheads are exposed to high levels of bycatch mortality in industrial USA and international longlines, and also in illegal, unreported and unregulated (IUU) longline fisheries (Wetherall et al. 1993, Polovina et al. 2003, Lewison et al. 2004b). But many juvenile and subadult loggerhead turtles also aggregate in large numbers off the Pacific coast of Baja California Sur, Mexico (BCS), presumably to forage until they reach maturity and migrate back to Japan to reproduce (Ramirez-Cruz et al. 1991, Nichols 2003). At BCS, small-scale fisheries have been shown to cause high levels of loggerhead mortality (Gardner \& Nichols 2001, Koch et al. 2006, Peckham et al. 2007a).

In addition to incidental bycatch and natural factors such as predation and disease, in northwestern Mexico sea turtles are killed for human consumption, despite a federal ban on turtle hunting and trade (Gardner \& Nichols 2001, Nichols 2003). As observed in the case of cetacean wildmeat (Millner-Gulland et al. 2003, Clapham \& Van Waerebeek 2007), turtle bycatch fuels both local consumption and black market trade in BCS. Sea turtles caught accidentally and retrieved dead are usually discarded; generally only live turtles are retained for personal consumption or black market sale (Nichols 2003). Turtles are also directly hunted for personal consumption or black market sale (Nichols \& Safina 2004). Human consumption is an important source of mortality for loggerhead turtles at BCS (Koch et al. 2006), despite associated human health risks (Aguirre et al. 2006).

Large numbers of loggerhead carcasses stranded each summer at BCS have been attributed to bycatch in local fisheries, but it was not possible to directly link strandings to bycatch mortality because turtle carcasses rarely show evidence of fisheries interactions
(Gardner \& Nichols 2001, Koch et al. 2006). Observations of small-scale fisheries at BCS uncovered a strong correspondence between the seasonality of loggerhead turtle bycatch and strandings from 2003 to 2005, revealing that a large proportion of strandings result from local fisheries bycatch (Peckham et al. 2007a).

Assessing mortality of oceanic species is notoriously difficult. Mortality rates have been inferred from telemetry observations, but these are limited to tracked animals, resulting in generally small sample sizes due to high costs (Hays et al. 2003, Block et al. 2005). Shoreline and town surveys for stranded and consumed carcasses can provide mortality data for species that frequent nearshore waters, but these severely underestimate overall mortality because (1) surveys are usually limited to a small fraction of coastlines and (2) the majority of turtles that die at sea either naturally or due to bycatch do not strand (Epperly et al. 1996, Hart et al. 2006, Leeney et al. 2008, Tomás et al. 2008, this Theme Section).

As with terrestrial wildmeat (or bushmeat) consumption, assessment of turtle consumption and black market trade through carcass surveys severely underestimates this important mortality source because carcasses may be discarded at sea or in unpopulated areas, and live turtles are exported to distant markets (Millner-Gulland et al. 2003, Brashares et al. 2004, Koch et al. 2006, A. Mancini \& V. Koch unpubl. data). Observations of fisheries bycatch also provide mortality data, but these are limited to the small proportion of vessels that can be observed.

Here, we integrated 3 different approaches to assess anthropogenic mortality of loggerhead turtles at BCS, Mexico. Following Koch et al. (2006) and extending results reported in Peckham et al. (2007a) by 2 more years we quantified (1) strandings of loggerhead turtles at an index shoreline from 2003 to 2007; (2) strandings of turtles at 12 other shorelines in the BCS region; (3) carcasses from surveys of 21 towns and fish camps plus their dumpsites; and (4) annual mortality rates of turtles taken as bycatch by 2 small-scale fishing fleets observed from 2005 to 2007 . Based on these data, we estimated annual loggerhead mortality in regional small-scale fisheries, exclusive of mortality due to bycatch in additional fisheries, hunting, and natural factors including predation and disease.

\section{MATERIALS AND METHODS}

Study area. Our study area extended along the Pacific coast of Baja California Sur, Mexico, from the Vizcaino Peninsula $\left(27^{\circ} 50^{\prime} \mathrm{N}, 115^{\circ} 05^{\prime} \mathrm{W}\right)$ to Bahía Magdalena $\left(24^{\circ} 30^{\prime} \mathrm{N}, 112^{\circ} 00^{\prime} \mathrm{W}\right.$; Fig. 1). The Bight of Ulloa (Fig. 1) is an important high-use area for loggerhead turtles 


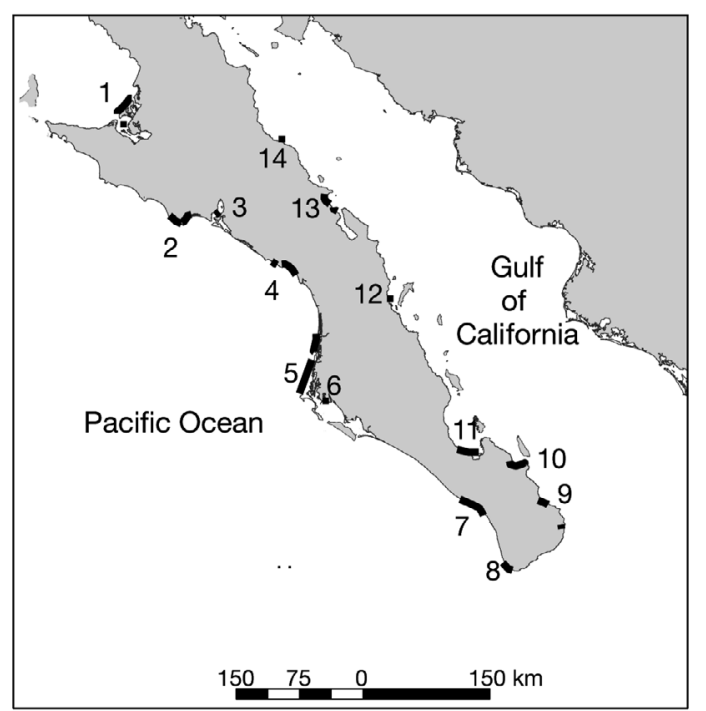

Fig. 1. Study area, including the shoreline of Playa San Lázaro. Shorelines (S) and/or dumpsites (D) were surveyed at each site: 1, Guerrero Negro (S/D); 2, Punta Abreojos (S/D); 3, Laguna San Ignacio (S/D); 4, San Juanico (S/D); 5, Playa San Lázaro (S); 6, Bahia Magdalena (S/D); 7, Todos Santos (S); 8, Los Cabos (S); 9, Cabo Pulmo (S); 10, Bahia La Ventana (S/D); 11, La Paz (S); 12, Loreto (S/D); 13, Mulegé (S/D); 14, Santa Rosalia (D)

(Ramirez-Cruz et al. 1991, Peckham et al. 2007a) and loggerhead turtles also occur irregularly in the waters of the Sea of Cortez (Nichols 2003, Seminoff et al. 2004).

Sampling. Bycatch observations: We accompanied fishing crews of Puerto López Mateos BCS on 21 daytrips using bottom-set gillnets from 23 July to 11 August 2006 and 6 August to 4 September 2007. The observed trips were made opportunistically and resulted in 18 trips observed in deep areas (32 to $45 \mathrm{~m}$ depths). Day trips consisted of a single haul of each net each between 06:00 and 14:00 h Pacific Standard time (PST). Fishers worked from 6 to $8 \mathrm{~m}$ outboard-powered skiffs and targeted primarily California halibut Paralichthys californicus, using $20.3 \mathrm{~cm}$ stretched mesh monofilament gillnets of 100 to $200 \mathrm{~m}$ length and 3 to 6 $\mathrm{m}$ height. We interviewed 2 master fishermen from Puerto Lopez Mateos to assess the effort of the local gillnet fleet in terms of ranges of the number of boats fishing $\mathrm{d}^{-1}$ and days fished $\mathrm{yr}^{-1}$.

On 16 August 2006, we made 1 daylong bottom-set longline trip with a fishing crew from Santa Rosa, BCS, during which 236 hooks were checked and baited. Longlines targeted demersal fish and were anchored in 85 to $105 \mathrm{~m}$ depths and checked daily. Fishers used freshly caught mackerel or bycaught tuna or marlin for bait on 'Japanese J-hooks' with inflected shanks or 14/0 circle hooks. We interviewed the president of the Santa Rosa fishing cooperative to assess the effort of the longline fleet.
In both fleets we recorded the number, species, condition, and measurements of sea turtles captured. For both fleets, fishing and observations were conducted exactly as in Peckham et al. (2007a) in order to pool and analyze data.

Estimating annual bycatch: To extrapolate the range of annual loggerhead bycatch in the 2 observed fleets we combined observed bycatch and mortality rates with reported fishing effort levels for each fleet, and used Monte Carlo simulations to incorporate all known sources of uncertainty in our data. Specifically, we developed a simple iterative model that allowed for random variation in 4 different parameters: (1) the number of fishing days season ${ }^{-1}$; (2) the number of boats fishing $\mathrm{d}^{-1}$; (3) the bycatch rate (turtles caught boat $^{-1}$ fishing $\mathrm{d}^{-1}$ ); and (4) the mortality rate of bycaught turtles. For the first 2 variables we utilized the range of values reported by master fishermen to set upper and lower bounds and assumed that variation could be modeled by uniform random numbers drawn from within these ranges. For the daily bycatch rate, we pooled the bycatch observations reported here with those from the same fleets in 2005 (Peckham et al. 2007a), for gillnet $(n=35)$ and long-line trips $(n=8)$ to fit probability distributions, and for each iteration of the model we drew numbers randomly from the appropriate distribution. For this step we first evaluated 5 alternative probability distributions: 2 continuous (normal and log-normal) and 3 discreet (binomial, poisson and negative binomial). Based on a comparison of Akaike's information criterion (AIC) values (Hilborn \& Mangel 1997), the negative binomial provided the best fit to bycatch data for both fleets (Fig. 2). For the parameter representing probability that a bycaught turtle would be killed, we fitted binomial distributions to our raw data on bycatch mortality rates and used these fitted distributions to generate random per-day mortality rates. For parameter estimates and distributions used for model simulations see Table 2. We ran the Monte Carlo model for 100000 iterations for both fleets; every iteration simulated bycatch and mortality of turtles over 1 fishing season. The result was a frequency distribution of seasonal loggerhead bycatch and mortality estimates from which we calculated $95 \%$ confidence limits $\left(\mathrm{CL}_{95}\right)$. Finally, we combined the estimates to arrive at the total projected annual loggerhead bycatch mortality for the 2 observed fleets.

Shoreline and town mortality surveys: Continuing the protocol employed from 2003 to 2005 (Peckham et al. 2007a), from January 2006 through December 2007 we conducted shoreline surveys by all-terrain vehicle (ATV) on daily (May to September) and weekly (October to April) schedules along the $44.3 \mathrm{~km}$ Playa San Lázaro (Fig. 1). Furthermore, we conducted shoreline 

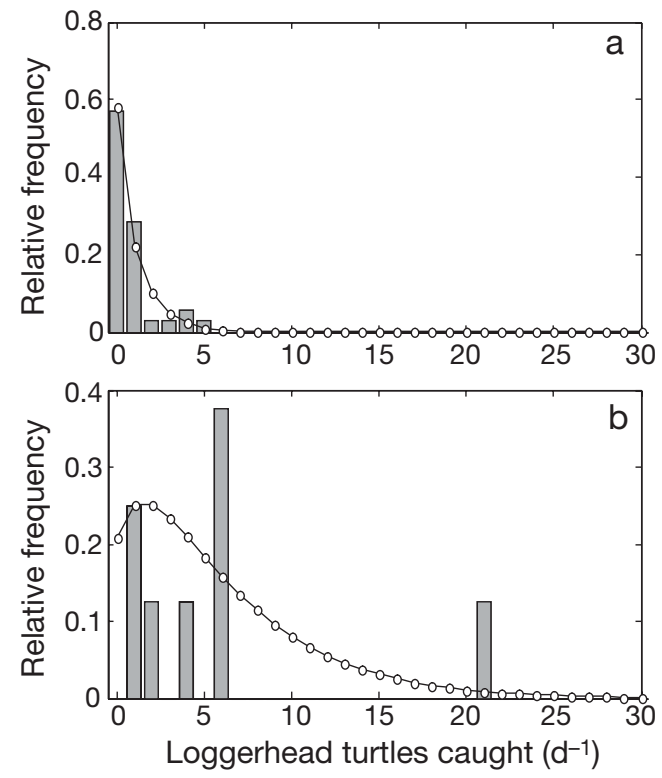

Fig. 2. Caretta caretta. Per-day bycatch rates for (a) bottom-set gillnet and (b) longline fleets. Negative binomial distributions $(O)$ were fit to raw data from observer trips (bars) using maximum likelihood techniques and these distributions were used to generate random values for Monte Carlo simulations (see 'Estimating annual bycatch' in 'Materials and methods' for details)

surveys by ATV once every 2 mo along each of the 12 shorelines on both coasts of BCS, totaling $299.7 \mathrm{~km}$ from February 2006 to December 2007. Overall we surveyed $344 \mathrm{~km}$ of shoreline, representing $15 \%$ of the $\sim 2200 \mathrm{~km}$ BCS coast. We also monitored sea turtle mortality in 21 towns and fish camps plus their dumpsites, representing 20 to $25 \%$ of all coastal communities in BCS (Fig. 1).

All turtle carcasses encountered were identified, measured, and marked to avoid recounts. Data recorded on each stranded carcass included observer name, stranding date, species, turtle number by day, location, curved carapace length and width (CCL and CCW, respectively), tag numbers (if present), sex of carcass (when externally obvious), condition of carcass (decomposition state), cause of death (if possible) and observer notes. CCL was taken from the nuchal notch to the posterior marginal tip. CCW was taken at the widest part of the shell.

Human consumption of loggerheads. Based on surveys of towns and dumps we determined minimum annual levels of turtle consumption in BCS coastal communities. We assumed that the majority of turtles consumed locally were caught as bycatch and thus did not add observed consumption to bycatch in calculating overall mortality.

Due to the clandestine nature of black market trade for sea turtles and the fact that trafficked turtles are often exported from the region alive (Nichols 2003, Koch et al. 2006), we could not assess mortality due to hunting. Thus our minimum estimate of anthropogenic mortality for loggerheads in the region was limited to bycatch in the 2 observed fleets and resulting consumption, exclusive of anthropogenic mortality due to hunting and natural mortality due to predation, disease and other natural factors.

Length frequency analysis. We constructed length frequency distributions for loggerhead turtles and estimated the percentage of adults. Length at maturity in females is close to average nesting length in loggerhead sea turtles (Frazer \& Ehrhart 1985, Hatase et al. 2004) and we used the average size of Japanese nesters as an approximation of length at maturity: $91 \mathrm{~cm}$ (CCL) (Kamezaki et al. 1995, Hatase et al. 2004).

We compared the length distribution of stranded loggerhead turtles during the 5 yr of our study with data from 1995 (Nichols 2003), 1999 (Gardner \& Nichols 2001), and 2000 to 2002 (Koch et al. 2006) collected at Playa San Lázaro and the adjacent Playa Santa Maria using the same protocol. Straight carapace lengths (SCL) collected in prior studies were converted to CCL by using the conversion equation

$$
\mathrm{SCL}=(0.932 \times \mathrm{CCL})+0.369
$$

derived from turtles measured locally $\left(\mathrm{N}=163, \mathrm{r}^{2}=\right.$ 0.93, $\mathrm{p}<0.001$ ). After conversions were completed, all CCL data were rounded to the nearest $\mathrm{cm}$.

The increasing trend in average length of stranded loggerheads from 1995 to 2003 described by Koch et al. (2006) was re-analyzed through 2007 to account for the difference between years in the number of turtles recorded. To ensure that the observed increase in length over time was not a result of differences in sample size or variance, we also analyzed the trend using both mean and median values for each year.

Analyses were conducted using SYSTAT 12 (Systat Software), with the exception of the Monte Carlo simulations, which were coded and run using MATLAB (Mathworks). Unless otherwise stated, results are presented as mean $\pm \mathrm{SD}$ and intervals represent either absolute ranges or, when denoted as ' $\mathrm{CL}_{95}$, ' the $95 \%$ confidence limits.

\section{RESULTS}

\section{Observed bycatch mortality}

In the summers of 2006 and 2007, we observed 17 loggerheads caught during 21 gillnet day-trips. Pooling these results with the observations we made of the same fleet in 2005 (Peckham et al. 2007a), we observed 28 loggerheads caught during 94 gillnet day-trips or 
Table 1. Caretta caretta. Observed bycatch rates and percent mortality by fishery and depth fished. Gillnets trips were observed from Puerto López Mateos, Baja California Sur, Mexico (BCS), 2005 to 2007 and longline trips from Santa Rosa, BCS, 2005 to 2006

\begin{tabular}{|c|c|c|c|c|c|c|c|}
\hline Fishery & $\begin{array}{c}\text { No. of } \\
\text { day-trips }\end{array}$ & $\begin{array}{l}\text { No. of turtles } \\
\text { caught }\end{array}$ & $\begin{array}{l}\mathrm{km} \text { of net } \\
\text { observed }\end{array}$ & $\begin{array}{l}\text { Turtles } \\
\mathrm{km}^{-1} \text { net }\end{array}$ & $\begin{array}{l}\text { Turtles d }{ }^{-1} \\
(\text { mean } \pm \mathrm{SE})\end{array}$ & $\begin{array}{l}\text { Range } \\
\text { turtles d } \mathrm{d}^{-1}\end{array}$ & $\begin{array}{l}\text { Percent } \\
\text { mortality }\end{array}$ \\
\hline Gillnet (all depths) & 94 & 28 & 76.0 & 0.37 & $0.30 \pm 0.09$ & $0-4$ & 68 \\
\hline Gillnet (shallow $<32 \mathrm{~m}$ ) & 59 & 0 & 49.1 & 0.00 & 0.00 & & \\
\hline \multirow[t]{2}{*}{ Gillnet (deep > 32 m) } & 35 & 28 & 26.8 & 1.04 & $0.80 \pm 0.22$ & $0-4$ & 68 \\
\hline & $\begin{array}{l}\text { No. of } \\
\text { day trips }\end{array}$ & $\begin{array}{c}\text { No. of turtles } \\
\text { caught }\end{array}$ & $\begin{array}{l}\text { Hooks } \\
\text { observed }\end{array}$ & $\begin{array}{c}\text { Turtles } \\
1000 \text { hooks }^{-1}\end{array}$ & $\begin{array}{l}\text { Turtles d }{ }^{-1} \\
(\text { mean } \pm \mathrm{SE})\end{array}$ & $\begin{array}{l}\text { Range } \\
\text { turtles d } \mathrm{d}^{-1}\end{array}$ & $\begin{array}{l}\text { Percent } \\
\text { mortality }\end{array}$ \\
\hline Longline (85-105 m) & 8 & 48 & 1636 & 29 & $6.00 \pm 2.30$ & $1-21$ & 90 \\
\hline
\end{tabular}

$0.3 \pm 0.1$ loggerheads boat ${ }^{-1} \mathrm{~d}^{-1}$ (mean $\pm \mathrm{SE}$ ) during the summers of 2005 to 2007). Sixty-eight percent of loggerheads were landed dead. All were caught in bottom-set gillnets during the 35 day-trips observed at the fleet's deepest fishing area (32 to $45 \mathrm{~m}$ ), where $0.8 \pm 0.2$ loggerheads were caught boat ${ }^{-1} \mathrm{~d}^{-1}$ (mean \pm $\mathrm{SE}$ ) at deep fishing grounds (Table 1). Across all depths, 0.37 loggerheads were caught $\mathrm{km}^{-1}$ gillnet; in waters deeper than $32 \mathrm{~m}, 1.04$ loggerheads were caught $\mathrm{km}^{-1}$ gillnet. Loggerheads retrieved from gillnets were large juveniles $(73.3 \pm 8.6 \mathrm{~cm}$ CCL) and showed no signs of fisheries interaction.

The 2 master fishermen interviewed from Puerto López Mateos reported that the local gillnet fleet numbered up to 75 boats from 2006 to 2007, with 5 to 20 boats fishing the fleet's deep area each day (32 to $45 \mathrm{~m}$ depths). Crews reportedly made 70 to 100 daylong trips to fish the fleet's deep area from May to September in 2005 through 2007 (J. Lucero \& M. Romero pers. comm.).

Twenty-one loggerheads were caught during the single longline day-trip observed in 2006, and fishers reported that this number was not unusual; 4 other boats that fished the same day caught similar numbers of loggerheads (A. Gaos pers. obs.). Pooling these new data with results from Peckham et al. (2007a), we observed 48 loggerheads during 8 longline day-trips (total 1636 hooks), resulting in a bycatch rate of 29.3 loggerheads 1000 hook $^{-1}$. Loggerheads were caught on all observed longline day-trips $(6.0 \pm 2.3$ loggerheads boat ${ }^{-1} \mathrm{~d}^{-1}$ mean $\pm \mathrm{SE}_{\text {; }}$ Table 1 ) . Of these loggerheads, $90 \%$ were landed dead or died shortly thereafter. Loggerheads caught in bottomset longlines were large juveniles $(77.7 \pm 6.2 \mathrm{~cm} \mathrm{CCL})$ and showed no morphological evidence of longline interaction.
The president of the Santa Rosa fishing cooperative reported that 5 to 8 boats of his fleet fished bottom-set longlines from 35 to 55 day-trips $\mathrm{yr}^{-1}$ in 2005 to 2006 (E. de la Paz pers. comm.). In 2007 the Santa Rosa fleet permanently ceased fishing bottom-set longlines so no further observations were possible.

\section{Estimated loggerhead bycatch}

For the gillnet fleet, because bycatch was highly dependent on fishing depth, we limited our analysis to day-trips conducted in depths greater than $32 \mathrm{~m}$. Based on the Monte Carlo simulations, mean estimated bycatch rate in bottom-set gillnets for 2005 to 2007 was $0.8 \pm 1.29$ turtles caught boat ${ }^{-1} \mathrm{~d}^{-1}\left(\mathrm{CL}_{95}=0\right.$ to 5$)$, or $830 \pm 102$ turtles season $^{-1}$. For bycaught turtles, the probability of mortality was $68 \%\left(\mathrm{CL}_{95}=48\right.$ to $84 \%$; Table 2). The mean estimated seasonal mortality for turtles in the Puerto Lopez Mateos gillnet fleet for 2005 through 2007 was 547 loggerheads $\mathrm{yr}^{-1}\left(\mathrm{CL}_{95}=356\right.$ to 777; Fig. 3).

For the bottom-set longline fishery, the mean estimated bycatch rate for 2005 to 2006 was $5.9 \pm 5.35$ tur-

Table 2. Caretta caretta. Parameter estimates and distributions used for Monte Carlo simulations of bycatch in gillnet and longline fleets. CL $_{95}$ : $95 \%$ confidence limits

\begin{tabular}{|c|c|c|c|c|}
\hline & Distribution & $\begin{array}{l}\text { Parameter } \\
\text { values }\end{array}$ & $\begin{array}{c}\text { Predicted } \\
\text { mean } \pm \text { SD }\end{array}$ & $\begin{array}{l}\text { Predicted } \\
\quad \mathrm{CL}_{95}\end{array}$ \\
\hline \multicolumn{5}{|l|}{ Gillnet $>32 \mathrm{~m}$} \\
\hline Day-trips $\mathrm{yr}^{-1}$ & Uniform & $\operatorname{Min}=70, \max =100$ & $\mathrm{n} / \mathrm{a}$ & $\mathrm{n} / \mathrm{a}$ \\
\hline Boats $\mathrm{d}^{-1}$ & Uniform & $\operatorname{Min}=5, \max =20$ & $\mathrm{n} / \mathrm{a}$ & $\mathrm{n} / \mathrm{a}$ \\
\hline Turtles $\mathrm{d}^{-1}$ & Neg. binomial & $\mathrm{R}=0.734, \mathrm{p}=0.478$ & $0.8 \pm 1.29$ & $0-5$ \\
\hline$\%$ mortality & Binomial & $\mathrm{p}=0.68$ & $68 \%$ & $48-84 \%$ \\
\hline \multicolumn{5}{|l|}{ Longline } \\
\hline Trips $\mathrm{yr}^{-1}$ & Uniform & $\operatorname{Min}=35, \operatorname{Max}=55$ & $\mathrm{n} / \mathrm{a}$ & $\mathrm{n} / \mathrm{a}$ \\
\hline Boats d $\mathrm{d}^{-1}$ & Uniform & $\operatorname{Min}=5, \operatorname{Max}=8$ & $\mathrm{n} / \mathrm{a}$ & $\mathrm{n} / \mathrm{a}$ \\
\hline Turtles d ${ }^{-1}$ & Neg. binomial & $\mathrm{R}=1.516, \mathrm{p}=0.205$ & $5.9 \pm 5.35$ & $0-20$ \\
\hline$\%$ mortality & Binomial & $\mathrm{p}=0.89$ & $89 \%$ & $77-96 \%$ \\
\hline
\end{tabular}




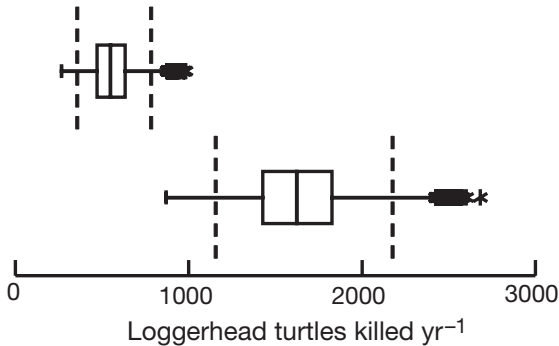

Fig. 3. Caretta caretta. Estimated bycatch mortality from 2 fleets of Baja California Sur, Mexico, the bottom-set gillnet (above) and longline fleets (below). Distributions were generated from 100000 iterations of a Monte Carlo model parameterized from observed bycatch and mortality data and reported fishing effort levels (see Table 2 for parameter values and 'Materials and methods: Estimated annual bycatch' for details). Dashed lines represent 95\% confidence limits for each fleet

tles caught boat ${ }^{-1} \mathrm{~d}^{-1}\left(\mathrm{CL}_{95}=0\right.$ to 20 ), or $1885 \pm 286$ turtles season ${ }^{-1}$. For bycaught turtles, the probability of mortality was $89 \%\left(\mathrm{CL}_{95}=77\right.$ to $96 \%$; Table 2$)$. The mean estimated seasonal mortality of turtles in the Santa Rosa longline fleet for 2005 and 2006 was 1635 loggerheads $\mathrm{yr}^{-1}\left(\mathrm{CL}_{95}=1160\right.$ to $2174 ;$ Fig. 3$)$. These estimates result in a total projected bycatch mortality of 2182 loggerheads $\mathrm{yr}^{-1}\left(\mathrm{CL}_{95}=1516\right.$ to 2951) for both fleets combined.

\section{Shoreline and town mortality surveys}

From 2003 to 2007 we encountered a total of 2719 loggerhead carcasses on shorelines and in and around towns of BCS. A total of 2385 of the carcasses were found along the $44.3 \mathrm{~km}$ Playa San Lázaro from 2003 to 2007, resulting in $476 \pm 274$ carcasses $\mathrm{yr}^{-1}$ at Playa San Lázaro. Of the loggerhead carcasses encountered at Playa San Lázaro, $70 \%$ (1674) were observed from May to September, corresponding to seasonal operations of small-scale fisheries primarily working bottomset gillnets (Table 3). Stranded carcasses at Playa San
Table 4. Caretta caretta. Mean and SD of curved carapace length (CCL) measured at Bahía Magdalena, Baja California Sur, Mexico, from 1995 to 2007, with percent of individuals with CCL <50 cm. Data from 1995, 1999, and 2000 to 2002 were taken from Nichols (2003), Gardner \& Nichols (2001) and Koch et al. (2006), respectively

\begin{tabular}{|ccrcc|}
\hline & Mean CCL & SD & $\%<50 \mathrm{~cm}$ & N of carcasses \\
\hline 1995 & 57.5 & 13.5 & 29 & 49 \\
1999 & 62.0 & 13.0 & 16 & 63 \\
2000 & 67.9 & 9.8 & 3 & 152 \\
2001 & 68.1 & 9.2 & 3 & 184 \\
2002 & 69.1 & 8.6 & 2 & 270 \\
2003 & 70.5 & 9.4 & 2 & 325 \\
2004 & 69.4 & 10.5 & 3 & 144 \\
2005 & 72.9 & 9.4 & 2 & 334 \\
2006 & 72.9 & 8.5 & 1 & 795 \\
2007 & 70.5 & 9.2 & 2 & 320 \\
\hline
\end{tabular}

Lázaro from 2003 to 2007 were encountered at mean rates of 0.15 loggerheads $\mathrm{km}^{-1} \mathrm{~d}^{-1}$ annually and 0.25 loggerheads $\mathrm{km}^{-1} \mathrm{~d}^{-1}$ from May to September. Most of the stranded turtles $(95 \%)$ for which data were collected were in moderately to very decomposed condition. Eighty-five turtles (4.2\%) stranded in fresh condition, and 9 stranded alive. Fourteen stranded carcasses showed evidence of fisheries interactions, evidenced by hooks or entanglement in fishing gear. Nine of 1918 $(0.5 \%)$ carcasses measured had a CCL of $91 \mathrm{~cm}$ or greater.

Fewer carcasses (277) were encountered during bimonthly surveys of 12 additional shorelines in the region from February 2006 through December 2007, yielding a 2 yr mean of 138.5 loggerhead carcasses $\mathrm{yr}^{-1}$. Combined, the mean 476 loggerhead carcasses that stranded along the $44 \mathrm{~km}$ Playa San Lázaro from 2003 to 2007 and the mean 138.5 that stranded at our other regional survey sites from 2006 to 2007 total an average of $\sim 600$ carcasses $\mathrm{yr}^{-1}$.

We encountered 57 carcasses during bimonthly surveys of 21 towns, fish camps and surrounding dumpsites in the region from February 2006 through

Table 3. Caretta caretta. Number of carcasses encountered along the $44.3 \mathrm{~km}$ Playa San Lázaro from 2003 to 2007

\begin{tabular}{|c|c|c|c|c|c|c|c|c|c|c|c|c|c|c|}
\hline & Jan & Feb & Mar & Apr & May & Jun & Jul & Aug & Sep & Oct & Nov & Dec & Total & $\begin{array}{c}\text { May-Sep } \\
\text { total }\end{array}$ \\
\hline 2003 & 7 & 11 & 5 & 5 & 68 & 75 & 73 & 92 & 36 & 14 & 7 & 1 & 394 & 344 \\
\hline 2004 & 4 & 2 & 4 & 4 & 7 & 31 & 55 & 37 & 8 & 42 & 23 & 3 & 220 & 138 \\
\hline 2005 & 8 & 3 & 18 & 11 & 27 & 46 & 33 & 149 & 44 & 15 & 12 & 2 & 368 & 299 \\
\hline 2006 & 4 & 2 & 1 & 2 & 2 & 19 & 84 & 243 & 145 & 352 & 76 & 11 & 941 & 493 \\
\hline 2007 & 6 & 14 & 2 & 4 & 15 & 30 & 134 & 119 & 102 & 16 & 16 & 4 & 462 & 400 \\
\hline Mean & 6 & 6 & 6 & 5 & 24 & 40 & 76 & 128 & 67 & 88 & 27 & 4 & 477 & 335 \\
\hline
\end{tabular}




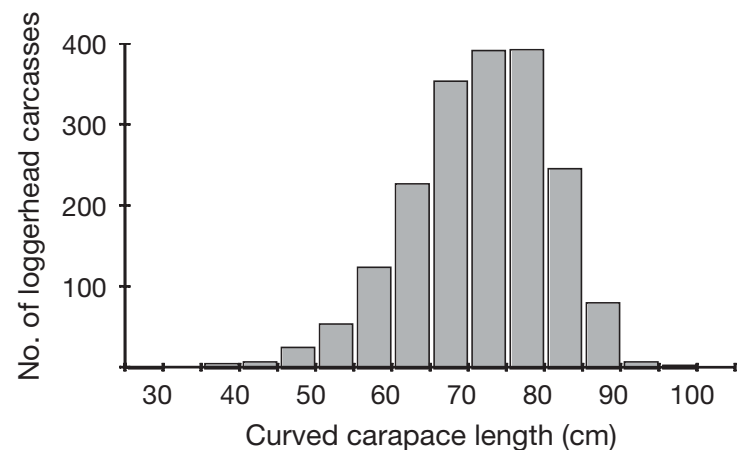

Fig. 4. Caretta caretta. Size frequency of stranded carcasses measured at Playa San Lázaro from 2003 to 2007 (N = 1918)

December 2007, yielding a 2 yr mean of 28.5 loggerheads consumed $\mathrm{yr}^{-1}$. All carcasses encountered in towns, fish camps, and surrounding dumps showed signs of human consumption (e.g. cuts, burns, harpoon holes).

An anomalous mass-stranding event occurred from August to November 2006, during which 816 loggerhead carcasses were encountered at Playa San Lázaro (Table 3). During 19 to 21 October 2006, tissues were collected from 56 turtles in various states of decomposition. Full necropsies were conducted on 12 individuals stranded in fresh condition. Several bacteria were isolated from these specimens but no common disease condition could explain the stranding event (A. Aguirre \& H. M. Zepeda unpubl. data).

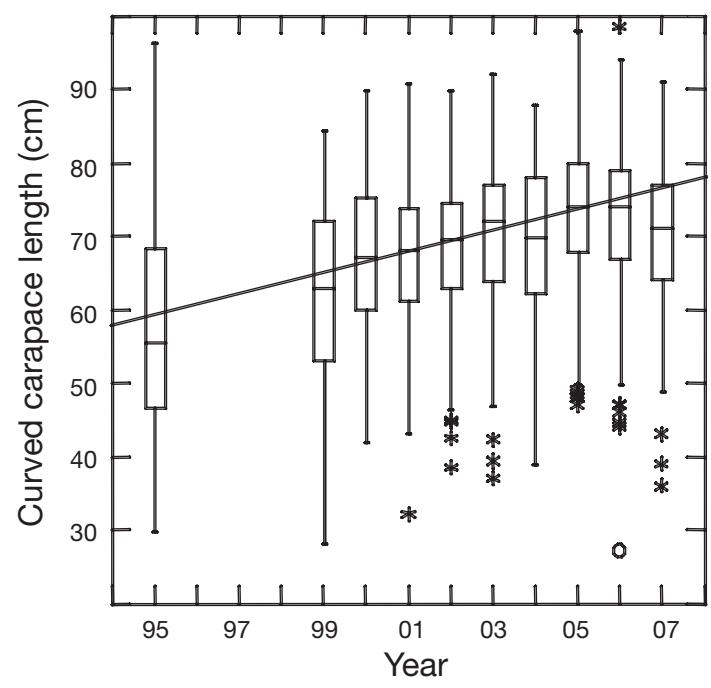

Fig. 5. Caretta caretta. Distribution and mean length (solid line) of carcasses measured from the study area 1995 to 2007. Data from 1995, 1999, and 2000 to 2002 were taken from Nichols (2003), Gardner \& Nichols (2001) and Koch et al. (2006), respectively

\section{Length distribution of loggerhead carcasses}

Length frequency histograms showed that all but 9 stranded loggerhead carcasses were of juvenile size (71.8 $\pm 9.2 \mathrm{~cm}$ CCL, $\mathrm{N}=1918$; Fig. 4). The length of stranded loggerhead carcasses increased significantly from 1995 to 2007 ( $\mathrm{N}=2636, \mathrm{r}^{2}=0.847, \mathrm{p}<0.0001$; Fig. 5). The proportion of juvenile turtles $<50 \mathrm{~cm} \mathrm{CCL}$ decreased precipitously over the same period (Table 4).

\section{DISCUSSION}

Many juvenile loggerhead turtles die at BCS each year. Based on (1) our intensive surveys of an index shoreline from 2003 to 2007; (2) bimonthly surveys of shorelines and towns across the region from 2006 to 2007; and (3) observations of bycatch by 2 small-scale fishing fleets, we estimated that 1500 to 2950 loggerhead turtles $\mathrm{yr}^{-1}$ died at Baja California Sur from 2005 to 2006. Our assessment represents a conservative estimate of bycatch mortality in small-scale fisheries. Actual anthropogenic mortality due to bycatch in additional small- and industrial-scale fleets and hunting, which we could not assess in this study, is likely to be considerably higher. This human-caused mortality is additive to natural mortality, including disease and predation, the rates of which are currently unknown.

\section{Bycatch mortality}

The minimum annual bycatch estimate (1500 loggerheads $\mathrm{yr}^{-1}$ ) for 2005 to 2006 in the 2 small-scale fleets observed represents an increase from the previously reported estimate (1000 loggerheads $\mathrm{yr}^{-1}$ ), which was based only on observations conducted in 2005 (Peckham et al. 2007a). New data collected in 2006 and 2007 resulted in more comprehensive observations of bottom-set fisheries, augmenting the confidence of our estimate of annual bycatch mortality for the 2 fleets we evaluated. Furthermore, our modeling approach more rigorously accounts for all sources of uncertainty, including sampling error (or observer error), the estimation error associated with fitting of probability distributions, and the process error inherent in stochastic rates of bycatch and mortality. Thus, the lower $95 \%$ confidence limit (1516 loggerheads killed $\mathrm{yr}^{-1}$ ) represents a very conservative estimate of actual mortality.

The observed bycatch rates of small-scale longlines (29 loggerheads 1000 hooks $^{-1}$ ) and gillnets (1.04 loggerheads $\mathrm{km}^{-1}$ gillnet; Table 2) are orders of magnitude higher than industrial bycatch rates reviewed in Peckham et al. (2007a). We attribute the perennially 
high bycatch and stranding rates described here to the overlap of locally intense small-scale fisheries with the very high local abundance of loggerheads (Seminoff et al. 2006, Peckham et al. 2007a). All bycatch of loggerheads in gillnets occurred in nets set in waters deeper than $32 \mathrm{~m}$, corresponding to the inshore margin of the loggerhead high use area described in Peckham et al. (2007a). Moreover, the high bycatch rates of the Santa Rosa longline fleet were observed in depths greater than $85 \mathrm{~m}, 10$ to $20 \mathrm{~km}$ further offshore from the gillnet deep fishing grounds, in the core of the loggerhead high use area (Peckham et al. 2007a). These unusually high bycatch rates are corroborated by what are apparently the highest strandings rates reported worldwide. Our new results emphasize that where high-use areas of small-scale fisheries and megafauna overlap, very high rates of bycatch can ensue that may jeopardize the persistence of vulnerable or endangered megafauna populations.

Loggerhead bycatch mortality for the region is likely to be considerably higher than the range we estimated because our assessment included just 2 of 12 or more fleets that fish at BCS. As is typical worldwide, assessment of bycatch in small-scale fisheries is extremely difficult, because (1) hundreds of boats work along the isolated $700 \mathrm{~km}$ coastline that borders the BCS loggerhead high use area; (2) space for observers is limited on small boats; (3) fishers are versatile and switch methods, gear and fishing areas rapidly and frequently to maximize landings; and (4) fishers may fear that bycatch observations are not in their best interests and thus may alter their behavior when observers are aboard.

For these reasons our observations were limited to just 2 fleets, but additional fleets operated from other communities that border the loggerhead high use area described in Peckham et al. (2007a). The fishing location and methods of these fleets suggests that they are also likely to catch considerable numbers of loggerheads. Furthermore, migrant fishers from mainland Mexico based at temporary camps along the same coastline fished bottom-set longlines and gillnets in the loggerhead high-use area, resulting in additional bycatch mortality (A. Gaos pers. obs.). Without direct observation we could not determine the bycatch of these boats due to the high variability of bycatch rates depending on gear and depths fished. However, given the bycatch rates above we estimate that their fishing could not have caused fewer than 75 additional loggerhead mortalities $\mathrm{yr}^{-1}$ and could have caused considerably more mortalities.

There are few records of industrial fisheries bycatch in the region. Class 6 tuna purse seiners that fish the region with $100 \%$ observer coverage have close to zero loggerhead bycatch (IATTC 2008). Smaller seiners known to work in the region are not observed comprehensively so bycatch rates are unavailable (M. Hall pers. comm.). Industrial shrimp vessels operate well inshore of the loggerhead hotspot (J. Lucero pers. comm.) Industrial longline vessels that fish the region with an order of magnitude more hooks per set may also cause high levels of bycatch.

\section{Shoreline mortality surveys}

The 2658 stranded loggerhead carcasses recorded from 2003 to 2007 represent a small fraction of all loggerheads that died naturally or were discarded by fishers in nearby waters because (1) our surveys were limited to just $15 \%$ of the BCS coastline and (2) only a small proportion of carcasses discarded are likely to have stranded. In the Northwest Atlantic, an upper limit of $\sim 15$ to $20 \%$ of loggerhead carcasses discarded at sea washed ashore locally, and the probability of stranding declined sharply with distance from shore (Epperly et al. 1996, Hart et al. 2006). The average of $\sim 600$ carcasses that stranded at $\mathrm{BCS} \mathrm{yr}^{-1}$ corroborate the high bycatch rates observed and overall mortality extrapolated in this study, yet represent only a small proportion of local mortality.

A comparison of stranding rates is problematic because they are extremely sensitive to survey frequency. Nonetheless, the sustained annual stranding rate we directly observed at Playa San Lázaro (0.15 loggerheads $\mathrm{km}^{-1} \mathrm{~d}^{-1}$ over $5 \mathrm{yr}$ ) is among the highest reported worldwide. By contrast, an estimated 90000 olive ridley carcasses stranded along the $480 \mathrm{~km}$ coast of Orissa, India, over 10 consecutive summers, yielding an overall mean stranding rate of 0.1 turtles $\mathrm{km}^{-1} \mathrm{~d}^{-1}$ (Pandav 2000, Shanker et al. 2004). In the USA, strandings are most frequent along the Atlantic coast of Florida. Along the $933 \mathrm{~km}$ Atlantic coast of Florida, $483 \pm 129$ loggerheads $\mathrm{yr}^{-1}$ stranded from 1998 to 2002, yielding a stranding rate of 0.001 loggerheads $\mathrm{km}^{-1} \mathrm{~d}^{-1}$ (STSSN 2007).

Cause of death of stranded carcasses was undetermined because (1) the majority were very decomposed and (2) unlike other megafauna, such as marine mammals, turtle carcasses discarded from gillnets and longlines in this study showed no signs of fisheries interaction. Peckham et al. (2007a) attributed the majority of seasonally high stranding rates to local small-scale fisheries bycatch, and the 2006 and 2007 strandings and bycatch data reported here add further support to this conclusion.

The cause of the mass-stranding event that occurred from August to October 2006 (Table 3) was not clear. Fishermen reported dead and dying turtles 35 to $55 \mathrm{~km}$ from shore (V. de la Toba pers. comm.). Red tides were also reported during the fall of 2006 (I. Romero Aguilar 
pers. comm.), but these are not unusual in the region. The small-scale fleets documented here could not have been responsible for the mortality after mid-September because by early September they had switched from bottom-set fishing in the loggerhead high-use area to near-shore fisheries that do not affect loggerheads. Several industrial longline vessels were operating in the loggerhead high-use area during aerial surveys conducted in September 2006 (J. Seminoff pers. comm.). Given the high bycatch per unit of effort (BPUE) of small-scale longlines (29 loggerheads 1000 hooks ${ }^{-1}$ ) and gillnets (1.0 loggerheads $\mathrm{km}^{-1}$ gillnet) observed in this study, a handful of industrial scale vessels setting thousands of hooks or tens of $\mathrm{km}$ of gillnet $\mathrm{d}^{-1}$ within the loggerhead high-use area could explain the anomalous stranding event.

Alternatively, anomalous mass-stranding events have been attributed to disease or harmful algal blooms, but none have shown the magnitude of strandings observed at Playa San Lázaro (Jacobson et al. 2006). Necropsies conducted on 12 carcasses stranded in fresh condition during the event revealed no common cause of death, but almost all carcasses stranded during the event were severely decomposed, so the carcasses that arrived fresh may not have died in the area where most of the carcasses came from and may not have died of the same cause. Population-level effects of disease in sea turtles are poorly understood (Herbst \& Jacobson 2003) and further research at BCS should focus on biotoxin exposure as a potential cause of death.

\section{Mortality due to human consumption}

The annual average of consumed carcasses we encountered in towns, fish camps and dumps was 28.5 and represents a minimum consumption level for the communities surveyed because (1) additional carcasses were undoubtedly discarded at sea or in the desert and (2) live turtles caught locally were exported for black market trade (Nichols 2003, Koch et al. 2006). Residents of BCS prefer black turtles Chelonia mydas and olive ridley turtles Lepidochelys olivaceae over loggerheads for consumption and trade (Koch et al. 2006). However, loggerhead turtles are consumed more frequently in communities where they are commonly bycaught (e.g. Puerto López Mateos; Koch et al. 2006), a pattern that underscores the important relationship between bycatch and wildmeat consumption and trade worldwide (Clapham \& Van Waerebeek 2007). Accordingly, it is reasonable to suggest that the majority of loggerheads consumed locally were caught incidentally in fisheries targeting other species and are therefore represented in our bycatch mortality estimates.
Our results showed a decrease in carcasses found consumed in and around Puerto López Mateos from those reported in Koch et al. (2006). However, increased awareness due to outreach and enforcement programs may also have caused people to conceal a higher proportion of consumed carcasses, contributing to underestimation of human consumption. As with terrestrial wildmeat (or bushmeat) consumption, assessment of turtle consumption and black market trade is particularly difficult and results in underestimation of this important population impact (MillnerGulland et al. 2003, A. Mancini \& V. Koch unpubl. data).

Nichols (2003) reported that hundreds of loggerheads were annually exported from the region for black market trade in the 1990s. During this study, fishers reported informally that dozens of loggerheads are hunted from each of several communities in the region for black market trade each year. Accordingly, we conservatively estimated that no fewer than 50 loggerheads $\mathrm{yr}^{-1}$ were poached and exported during the study period on top of the 1500 to $2950 \mathrm{yr}^{-1}$ killed due to local bycatch observations. Because poached turtles are invariably exported for sale, the carcasses of these 50 loggerheads $\mathrm{yr}^{-1}$ would not have been counted in the community surveys described above.

The fact that there were only dozens of loggerheads poached per year from each of several communities suggests that poaching levels have decreased since those reported by Nichols (2003). Preliminary survey data also suggested decreases in poaching and sale of loggerheads in the region (S. Delgado unpubl. data). Though poaching for trade appears to have decreased and pales in comparison to bycatch mortality, at a minimum of 50 loggerheads $\mathrm{yr}^{-1}$, it remains an important source of mortality for the endangered North Pacific population.

Our observations of turtle mortality due to human consumption are extremely conservative, and further research is essential for understanding its effects on the North Pacific loggerhead population. Molecular classification of wildmeat (Baker et al. 1996) and capture-recapture methods to estimate the number of individual animals taken (Baker et al. 2007) could be useful in the future.

\section{Size distribution}

The length distribution of stranded loggerhead carcasses increased significantly from 1995 to 2007 (Fig. 5). Because all samples were collected on adjacent Pacific beaches of Bahía Magdalena using the same protocol, differences found between years suggest trends in the local loggerhead population rather than sampling bias. Due to the decades-long matura- 
tion time of loggerheads, this increasing trend in turtle size may reflect both long-term declines in nesting described from Japan (Kamezaki et al. 2003) and also historically high bycatch of juvenile loggerheads in both high-seas driftnet (Wetherall et al. 1993) and longline fisheries (Lewison et al. 2004b). The decreasing proportion of smaller juveniles at BCS, especially from 2000 to 2007 (Table 3), could be related to sharp declines in nesting observed across all Japanese rookeries in the 1990s (Kamezaki et al. 2003, Chaloupka et al. 2008, N. Kamezaki et al. unpubl. data).

It is of great concern that almost all of the several thousand carcasses encountered from 2003 to 2007 were large juveniles because numerous studies have demonstrated the importance of the large juvenile size class to population growth in loggerhead turtles (Crouse et al. 1987, Crowder et al. 1994, Heppell et al. 2005). The large size of bycaught and stranded loggerheads exacerbates concern over the high mortality observed at BCS because of the resulting severe loss of reproductive potential for the population.

\section{Survivorship}

There is not sufficient information about the demography and distribution of North Pacific loggerheads to allow for a formal assessment of survivorship for juvenile loggerheads at BCS. However, we can derive a rough understanding of relative mortality rates and their population-level impacts by synthesizing available North Pacific loggerhead data with demographic schedules from other loggerhead populations (Heppell et al. 2003, Lewison et al. 2004a). Aerial surveys conducted over Pacific BCS waters resulted in estimates of from $\sim 5000$ to 15000 sightable loggerheads in the region (Seminoff et al. 2006).

Sightability of sea turtles during aerial surveys depends on the percent of time they spend at the surface. For loggerheads, published estimates of time spent at the surface range from 6 to $25 \%$ (Byles 1988, Houghton et al. 2002, Mansfield 2006) and surface time has been shown to vary significantly with water temperature, location and season (Mansfield 2006). Preliminary dive data suggest that loggerheads at BCS spent 50 to $80 \%$ of their time at the surface during daylight hours (S. H. Peckham unpubl. data), a finding that is consistent with the observation that loggerheads bask at the surface in BCS waters for considerable periods of the day (Pitman 1990, Ramirez-Cruz et al. 1991, Nichols 2003). These preliminary dive data from BCS thus suggest that the Seminoff et al. (2006) abundance estimate should be multiplied by a factor of 1.4 to 2. Accordingly, if we assume that $\sim 7000$ to 30000 loggerhead turtles are in Pacific BCS waters, the annual mortality estimate (1500 to 2950 loggerheads $\mathrm{yr}^{-1}$ ) suggests that 5 to $42 \%$ of loggerheads in BCS waters may die annually due to bycatch in the observed fleets, exclusive of all other sources of mortality (i.e. mortality due to bycatch in other small-scale and industrial fleets, poaching for black market trade, and natural mortality including disease and predation).

The proportion of juvenile loggerheads in the North Pacific population represented by those exposed to mortality in BCS waters remains unknown. Assuming a stable stage distribution in the population based on annual nesting numbers of 1500 females and a proportion of nesting-aged females of $1.8 \%$, Lewison et al. (2004b) estimated a population size of $\sim 335000$ loggerheads, 67000 of which would be larger juveniles. However, it is unlikely that the North Pacific loggerhead population meets the criteria of a stable age or stage distribution (Morris \& Doak 2002). Given the decrease in nesting numbers in recent decades (Kamezaki et al. 2003), the historical depletion of larger juvenile loggerheads in high-sea driftnets (Wetherall et al. 1993), the ongoing depletion in highsea longlines (Lewison et al. 2004b) and other fisheries (Lewison \& Crowder 2007), plus the small-scale fisheries bycatch described here and in Peckham et al. (2007a), it is likely that that the age distribution is highly skewed, with many fewer juveniles in the population than the 67000 expected from a stable stage distribution. Estimates of loggerhead abundance in BCS waters from aerial surveys corrected for submergence time suggest that upwards of $50 \%$ of larger juvenile loggerheads in the North Pacific population may utilize BCS waters. We therefore conclude that the high levels of fishing-related mortality reported here for BCS waters could have a profound impact on the trajectory of the North Pacific loggerhead population.

\section{CONCLUSIONS}

There have been a number of conservation success stories reported recently for sea turtles around the world, with increasing population sizes reported at rookeries of green, olive ridley, and Kemp's ridley turtles (Hays 2004, Broderick et al. 2006, Seminoff \& Shanker 2008). However, the mortality rates reported here highlight pressing conservation threats that remain for many sea turtle populations.

The highly productive waters of BCS have been revered for decades and recognized for centuries for the abundance and diversity of megafauna they attract (Steinbeck \& Ricketts 1941, Saenz-Arroyo et al. 2006). With perennially abundant prey including pelagic red 
crabs, sardine and squid (Aurioles-Gamboa 1995), it is unsurprising that loggerhead turtles and fishers alike frequent these waters. The unfortunate overlap between foraging loggerheads and fishers results in what may be the highest known rates of turtle bycatch and strandings worldwide. Given that estimated loggerhead mortality due to bycatch in 2 fleets observed at BCS exceeds 1500 loggerheads $\mathrm{yr}^{-1}$, we conclude that reduction of this mortality may be essential for the persistence and recovery of the North Pacific population. Consistent decreases in small juvenile loggerheads foraging at BCS suggest that a decline in neophytes nesting in Japan that originated from BCS should be expected over the next 2 decades.

Based on the results of our observations of their bycatch in 2005 and 2006, one of the fishing fleets we observed (Santa Rosa) retired their bottom-set longline gear from the loggerhead high-use area prior to their 2007 season (Rodgers 2008), potentially sparing hundreds of loggerhead individuals from bycatch in 2007 alone. This extraordinary conservation action resulted from at least 2 factors: (1) perceived decreases in the profitability of the fleet's longlines and (2) increased awareness of the Pacific-wide impacts of their local bycatch due to outreach programs conducted with the Grupo Tortuguero at Santa Rosa from 2005 to 2007, including direct participation in this research (Peckham et al. 2007a,b). The action of the leaders of this fleet may serve as an example for both fishers and conservation practitioners alike.

Conservation action by state and federal agencies is urgently needed to reduce bycatch and hunting at the loggerhead high-use area off the Pacific coast of BCS. Mexico is recognized worldwide for its successful protection of assorted migratory species and it has established marine protected areas along the Baja California peninsula. A proposed Mexican federal refuge managed in partnership with local fishing leaders could ensure that both fishers' livelihoods and loggerheads are conserved through sustainable fishing practices in the loggerhead high-use area (Peckham et al. 2007a). Though the high-use area is well defined, additional, higher precision tracking could enable identification of critical habitat within the high use area (Schofield et al. 2007). Further research should focus on (1) quantifying bycatch in other small- and industrial-scale fleets that fish the loggerhead highuse areas; (2) determining cause of death of loggerhead carcasses through full necropsies; (3) monitoring trends in bycatch, strandings, and relative abundance in the region; and (4) assessing sightability and abundance, and incorporating the results reported here to derive survivorship rates of loggerheads at BCS. Given the response of the Santa Rosa fleet to their involvement in our participatory research (Rodgers 2008), fur- ther work should be conducted in partnership with local fisher leaders to continue to engage them in developing locally sustainable conservation solutions.

Acknowledgements. We thank the fishers of Puerto A. Lopez Mateos, Santa Rosa and other Pacific BCS communities for their leadership and trust. We are very grateful to V. de la Toba Miranda, V. de la Toba Vallalolid, R. Rangel, J. Laudino, R. Ochoa, N. Rossi, E. Caballero, D. Wingfield, V. Cordi, R. Donadi, D. Purce, and all of ProCaguama and Grupo Tortuguero for field assistance. We thank J. Seminoff, T. Eguchi, and P. Dutton of NMFS-SWFSC for their counsel and encouragement. J. Estes, D. Croll, L. Crowder, D. Doak, J. Moore, and A. Aguirre provided critiques of the manuscript. G. Hays and 3 anonymous reviewers provided helpful reviews. This work was supported by NMFS-SWFSC, Western Pacific Fisheries Management Council (NOAA Grant FNA05 NMF4411092), David and Lucile Packard Foundation, ProPeninsula, PADI Foundation, CONACyT, Maurice Laing Foundation, Rufford Foundation, ESRI Conservation Programme and the Society for Conservation GIS. S.H.P. was supported with CILS-NSF and UCMEXUS graduate fellowships and awards. A.M. was supported with grants from the Rufford Foundation and SEMARNAT-Conacyt 2004 C04-277. Research was authorized by the Mexican government through SEMARNAP and SEMARNAT permits 150496-21303，280597-213-03，190698-213-03，280499-213-03，280700213-03, SGPA/DGVS/002 4661，SGPA/DGVS/10358, SGPA/ DGVS/03501/06, and SGPA/DGVS/03406/07. Carcass handling was in full compliance with CARC/IACUC protocol at University of California Santa Cruz.

\section{LITERATURE CITED}

Aguirre A, Tabor G (2004) Introduction: marine vertebrates as sentinels of marine ecosystem health. EcoHealth 1: $236-238$

Aguirre AA, Gardner SC, Marsh JC, Delgado SG, Limpus CJ, Nichols WJ (2006) Hazards associated with the consumption of sea turtle meat and eggs: a review for health care workers and the general public. EcoHealth 3:141-153

Aurioles-Gamboa D (1995) Distribucion y abundancia de la langostilla bentonica (Pleuroncodes planipes) en la plataforma continental de la costa oeste de la Baja California peninsula. In: Aurioles-Gamboa D, Balart EF (eds) La Langostilla: biología, ecología, y aprovechamiento. CIBNOR, La Paz, p 59-78

Baker CS, Cipriano F, Palumbi SR (1996) Molecular identification of whale and dolphin products from commercial markets in Korea and Japan. Mol Ecol 5:671-685

Baker CS, Cooke JC, Lavery S, Dalebout ML and others (2007) Estimating the number of whales entering trade using DNA profiling and capture-recapture analysis of market products. Mol Ecol 16:2617-2626

> Block BA, Teo SLH, Walli A, Boustany A and others (2005) Electronic tagging and population structure of Atlantic bluefin tuna. Nature 434:1121-1127

Bowen BW, Abreu-Grobois FA, Balazs GH, Kamezaki N, Limpus CJ, Ferl RJ (1995) Trans-Pacific migrations of the loggerhead turtle (Caretta caretta) demonstrated with mitochondrial-DNA markers. Proc Natl Acad Sci USA 92: 3731-3734

Brashares JS, Arcese P, Sam MK, Coppolillo PB, Sinclair ARE, Balmford A (2004) Bushmeat hunting, wildlife declines, and fish supply in West Africa. Science 306:1180-1183 
Broderick AC, Frauenstein R, Glen F, Hays GC and others (2006) Are green turtles globally endangered? Glob Ecol Biogeogr 15:21-26

Byles RA (1988) The behavior and ecology of sea turtles in Virginia. PhD thesis, Virginia Institute of Marine Science, Gloucester Point, VA

Chaloupka M, Kamezaki N, Limpus CJ (2008) Is climate change affecting the population dynamics of the endangered Pacific loggerhead sea turtle? J Exp Mar Biol Ecol 356:136-143

Clapham P, Van Waerebeek K (2007) Bushmeat and bycatch: the sum of the parts. Mol Ecol 16:2607-2609

> Crouse DT, Crowder LB, Caswell H (1987) A stage-based population model for loggerhead sea turtles and implications for conservation. Ecology 68:1412-1423

$>$ Crowder LB, Crouse DT, Heppell SS, Martin TH (1994) Predicting the impact of turtle excluder devices on loggerhead sea turtle populations. Ecol Appl 4:437-445

Epperly SP, Braun J, Chester AJ, Cross FA, Merriner JV, Tester PA, Churchill JH (1996) Beach strandings as an indicator of at-sea mortality of sea turtles. Bull Mar Sci 59: 289-297

Frazer NB, Ehrhart LM (1985) Preliminary growth models for green and loggerhead turtles in the wild. Copeia 73-79

Gardner SC, Nichols WJ (2001) Assessment of sea turtle mortality rates in the Bahía Magdalena region, Baja California Sur, México. Chelonian Conserv Biol 4:197-199

> Hart KM, Mooreside P, Crowder L (2006) Interpreting the spatio-temporal patterns of sea turtle strandings: going with the flow. Biol Conserv 129:283-290

> Hatase H, Matsuzawa Y, Sato K, Bando T, Goto K (2004) Remigration and growth of loggerhead turtles (Caretta caretta) nesting on Senri Beach in Minabe, Japan: life-history polymorphism in a sea turtle population. Mar Biol 144: 807-811

Hays GC (2004) Good news for sea turtles. Trends Ecol Evol 19:349-351

Hays GC, Broderick AC, Godley BJ, Luschi P, Nichols WJ (2003) Satellite telemetry suggests high levels of fishinginduced mortality in marine turtles. Mar Ecol Prog Ser 262:305-309

Heppell SS, Crowder LB, Crouse DT, Epperly S, Frazer NB (2003) Population models for Atlantic loggerheads: past, present, and future. In: Bolten $\mathrm{AB}$, Witherington $\mathrm{B}$ (eds) Loggerhead sea turtles. Smithsonian Institution Press, Washington, DC, p 255-273

Heppell SS, Heppell SA, Read AJ, Crowder LB (2005) Effects of fishing on long-lived marine organisms. In: Norse EA, Crowder LB (eds) Marine conservation biology. Island Press, Washington, DC, p 211-231

Herbst LH, Jacobson ER (2003) Practical approaches for studying sea turtle health and disease. In: Lutz PL, Musick JA, Wyneken J (eds) The biology of sea turtles. CRC Press, New York, p 385-410

Hilborn R, Mangel M (1997) The ecological detective: confronting models with data. Princeton University Press, Princeton, NJ

Houghton JDR, Broderick AC, Godley BJ, Metcalfe JD, Hays GC (2002) Diving behaviour during the internesting interval for loggerhead turtles Caretta caretta nesting in Cyprus. Mar Ecol Prog Ser 227:63-70

IATTC (Inter-American Tropical Tuna Commission) (2008) Annual Report of the Inter-American Tropical Tuna Commission. IATTC, La Jolla, CA

> Jackson JBC, Kirby MX, Berger WH, Bjorndal KA and others (2001) Historical overfishing and the recent collapse of coastal ecosystems. Science 293:629-638
Jacobson ER, Homer BL, Stacy BA, Greiner EC and others (2006) Neurological disease in wild loggerhead sea turtles Caretta caretta. Dis Aquat Org 70:139-154

Kamezaki N, Goto K, Matsuzawa Y, Nakajima Y, Omuta K, Sato K (1995) Carapace length and width of the loggerhead turtle Caretta caretta nesting in the coast of Japan. Umigame Newsletter Japan 26:12-13

Kamezaki N, Matsuzawa Y, Abe O al e (2003) Loggerhead turtles nesting in Japan. In: Bolten AB, Witherington B (eds) Loggerhead sea turtles. Smithisonian Books, Washington, DC, p 210-218

> Koch V, Nichols WJ, Peckham SH, de la Toba V (2006) Estimates of sea tutle mortality from poaching and bycatch in Bahia Magdalena, Baja California Sur, Mexico. Biol Conserv 128:327-334

Leeney R, Amies R, Broderick AC, Witt MJ, Loveridge J, Doyle J, Godley BJ (2008) Spatio-temporal analysis of cetacean strandings and bycatch in a UK fisheries hotspot. Biodivers Conserv 17:2323-2338

> Lewison RL, Crowder LB (2007) Putting longline bycatch of sea turtles into perspective. Conserv Biol 21:79-86

> Lewison RL, Crowder LB, Read AJ, Freeman SA (2004a) Understanding impacts of fisheries bycatch on marine megafauna. Trends Ecol Evol 19:598-604

> Lewison RL, Freeman SA, Crowder LB (2004b) Quantifying the effects of fisheries on threatened species: the impact of pelagic longlines on loggerhead and leatherback sea turtles. Ecol Lett 7:221-231

Mansfield KL (2006) Sources of mortality, movements and behavior of sea turtles in Virginia. PhD thesis, School of Marine Science, College of William and Mary, Gloucester Point, VA

Millner-Gulland EJ, Bennett EL, SCB 2002 annual meeting wild meat group (2003) Wild meat: the bigger picture. Trends Ecol Evol 18: 351-357

Morris WF, Doak DF (2002) Quantitative conservation biology. Sinauer Associates, Sunderland, MA

Myers RA, Worm B (2003) Rapid worldwide depletion of predatory fish communities. Nature 423:280-283

Nichols WJ (2003) Biology and conservation of sea turtles in Baja California, Mexico. PhD thesis, School of Renewable Resources, University of Arizona, Tucson, AZ

Nichols WJ, Safina C (2004) Lunch with a turtle poacher. Conservation in Practice 5:30-36

NMFS (National Marine Fisheries Service) (2007) NMFS and USFWS 5-year status review for the loggerhead sea turtle as listed under the Endangered Species Act of 1973. In: National Marine Fisheries Service, US Department of Commerce and US Fish \& Wildlife Service, Department of the Interior, Washington, DC

NRC (National Research Council) (1990) Decline of sea turtles: causes and prevention. NRC, National Academy Press, Washington, DC

NRC (1995) Science and the endangered species act. NRC, National Academy Press, Washington, DC

Pandav B (2000) Conservation and management of olive ridley sea turtles on the Orissa coast. PhD thesis, Utkal University, Bhubaneshwar

Peckham SH, Maldonado D, Walli A, Ruiz G, Nichols WJ, Crowder L (2007a) Small-scale fisheries bycatch jeopardizes endangered Pacific loggerhead turtles. PLoS One. doi:10.1371/journal.pone.0001041

Peckham SH, Laudino-Santillán J, Nichols WJ (2007b) Networks, knowledge, and communication: an integrated approach to empowering fishers to reduce turtle bycatch. In: Kennelly SJ (ed) By-catch reduction in the world's fisheries. Springer-Verlag, Dordrecht, p 253-260 
Pitman RL (1990) Pelagic distribution and biology of sea turtles in the eastern tropical Pacific. In: Richardson EH, Richardson JA, Donnelly M (eds) Proc 10th Annu Workshop Sea Turtles Biol Conserv. US Dept Commerce, NOAA Technical Memo. NMFS-SEC-278, p 143-148

Polovina JJ, Howell E, Parker DM, Balazs GH (2003) Divedepth distribution of loggerhead (Carretta carretta) and olive ridley (Lepidochelys olivacea) sea turtles in the central North Pacific: Might deep longline sets catch fewer turtles? Fish Bull (Wash DC) 101:189-193

Ramirez-Cruz JC, Ramirez IP, Flores DV (1991) Distribución y abundancia de la tortuga perica en la costa occidental de Baja California Sur, Mexico. Archelon 1:1-4

Rodgers T (2008) Slow, steady wins conservation race. San Diego Union Tribune, San Diego, CA, p A1

Saenz-Arroyo A, Roberts CM, Torre J, Carino-Olvera M, Hawkins JP (2006) The value of evidence about past abundance: marine fauna of the Gulf of California through the eyes of 16th to 19th century travellers. Fish Fish 7: 128-146

Schofield G, Bishop CM, MacLean G, Brown P and others (2007) Novel GPS tracking of sea turtles as a tool for conservation management. J Exp Mar Biol Ecol 347: 58-68

Seminoff JA, Shanker K (2008) Marine turtles and IUCN Red Listing: a review of the process, the pitfalls, and novel assessment approaches. J Exp Mar Biol Ecol 356:52-68

Seminoff JA, Resendiz A, Resendiz B, Nichols WJ (2004) Occurrence of loggerhead sea turtles in the Gulf of Cali-

Editorial responsibility: Brendan Godley,

University of Exeter, Cornwall Campus, UK forna México: evidence of life history variation in the Pacific Ocean. Herpetol Rev 35:24-27

Seminoff JA, Peckham SH, Eguchi T, Sarti-Martinez A, Rangel-Acevedo R, Forney KA, Nichols WJ (2006) Loggerhead turtle density and abundance along the Pacific coast of the Baja California peninsula, Mexico. In: Frick M, Panagopoulo A, Rees AF, Williams K (eds) Book of abstracts. Twenty Sixth Annual Symposium on Sea Turtle Biology and Conservation. International Sea Turtle Society, Athens, p 321

Shanker K, Pandav B, Choudhury BC (2004) An assessment of the olive ridley turtle nesting population in Orissa, India. Biol Conserv 115:149-160

Steinbeck J, Ricketts EF (1941) Sea of Cortez: a leisuly journal of travel and research. Viking Press, New York

STSSN (2007) Annual Strandings Reports. Sea Turtle Stranding and Salvage Network. Available at: www. sefsc.noaa.gov/seaturtleSTSSN.jsp

Tomás J, Gozalbes P, Raga JA, Godley BJ (2008) Bycatch of loggerhead sea turtles: insights from 14 years of strandings data. Endang Species Res 5:161-169

Wetherall JA, Balazs GH, Tokunaga RA, Yong MYY (1993) Bycatch of marine turtles in North Pacific high seas driftnet fishery and impacts on stock. In: Ito J (ed) INPFC symposium on biology, distribution and stock assessment of species caught in the high seas driftnet fishery in the North Pacific Ocean. Int $\mathrm{N}$ Pac Fish Comm, p 519-538

Submitted: March 9, 2008; Accepted: July 24, 2008 Proofs received from author(s): October 4, 2008 